\title{
Influence of Degree of Clay-Mineral Crystallization and Free Iron Oxide Content on the Cation Exchange Capacity of Catalina and Cialitos Soils
}

\author{
Raúl Pérez Escolar and M. A. Lugo López ${ }^{1}$ \\ INTRODUCTION
}

Catalina and Cialitos are rather extensive, deep soils of the Humid Uplands. Together with the Los Guineos, Alonso, and others they comprise the majority of the soils of the Coffee Region. Catalina is a Tropectic, clayey, oxidic, isohyperthermic Oxisol. ${ }^{2}$ Cialitos is an Orthoxic, clayey, oxidic isohyperthermic Ultisol. ${ }^{3}$ They both occur on areas with more than 75 inches of rainfall per year. Relief ranges from rolling to steep, but most of the hills are rounded and gently sloping with intervening ravines. Although they are both rather low in natural fertility, under good management they can be valuable productive soils. The key to their productivity lies in rational fertilization and liming. Minimum tillage is a must to assure conservation.

Cation exchange capacity is one of the most valuable critera for soil classification in modern schemes and for soil fertility. It can be defined as the ability of the soil to retain cations in readily available and exchangeable form.

It has long been recognized that organic matter and clay provide the sites for exchange reactions in soils. In Catalina and Cialitos soils, although similar in many respects, marked differences in exchange capacity have been observed. This paper proposes a possible theory to attempt to explain these differences.

\section{MATERIALS AND METHODS}

The pipette method as modified by Kilmer and Alexander $(5)^{4}$ was used in determining particle-size distribution. Originally it had been intended to use for the particle-size distribution samples on which free iron oxides had been determined. The reason was that iron and aluminum, because of their

1 Associate Soil Scientist and Soil Scientist, respectively, Agricultural Experiment Station, Mayagüez Campus, University of Puerto Rico, Río Piedras, P.R.

2 Order including soils with a horizon whose total exchange capacity is less than 16 meq. $/ 100 \mathrm{~g}$. where cations are less than $12 \mathrm{meq}$. The soils included in this order do not exhibit clay films, and the structure is either very weak or nonexistent.

a Order including soils with an argillic horizon with less than 35-percent base saturation, decreasing with depth. It has clayskins and a well-developed structure with a cation exchange capacity ranging between 16 and 24 meq. $/ 100 \mathrm{~g}$. of dry soil.

4 Numbers in parenthesis refer to Literature Cited, p. 154. 
flocculating ability, might interfere with a complete dispersion. It was found, however, that stable suspensions were obtained without this treatment, thus saving considerable time.

The chromic acid-reduction method proposed by Walkley and Black (7), was used in the determination of organic matter. When dealing with tropical soils this method has given most satisfactory results. The method proposed by Jeffries (4), namely, the potassium oxalate-oxalic acid-magnesium ribbon procedure, was used in the determination of free iron oxides. For the cation exchange capacity the ammonium acetate method developed by Schollenberger and Simon $(6)$ was used.

In the preparation of the sample for $\mathrm{X}$-rays the $2-\mu$ fraction was cleared of free oxides. Two portions of the clay of each soil were heated to $500^{\circ} \mathrm{C}$. and $700^{\circ} \mathrm{C}$. in order to clearly differentiate or discard any type of clay mineral which might behave like kaolinite, in case this was the clay found

TAHLE 1.-Dala on organic-maller content, particle-size distribution, free iron oxide content, and cation-exchange capacity of ('atalina and ('ialitos soils

\begin{tabular}{|c|c|c|c|c|c|c|}
\hline \multirow{2}{*}{ Soil } & \multirow{2}{*}{$\begin{array}{l}\text { Organic- } \\
\text { matter } \\
\text { content }\end{array}$} & \multicolumn{3}{|c|}{ Particle size distribution } & \multirow{2}{*}{$\begin{array}{c}\text { Frre iron } \\
\text { oxide content }\end{array}$} & \multirow{2}{*}{$\begin{array}{l}\text { Cation } \\
\text { exchange } \\
\text { capacity }\end{array}$} \\
\hline & & $\underset{0.05-2 \mathrm{~mm}}{\operatorname{sand-}}$ & $\mid \begin{array}{c}\text { Silt- } \\
0.002-0.05 \\
\mathrm{~mm}\end{array}$ & $\begin{array}{c}\text { Clay- } \\
<0.002 \mathrm{~mm}\end{array}$ & & \\
\hline Catalina & $\begin{array}{c}\text { Percent } \\
3.5\end{array}$ & $\begin{array}{l}\text { Percent } \\
12.0\end{array}$ & $\begin{array}{l}\text { Percent } \\
23.9\end{array}$ & $\begin{array}{l}\text { Percent } \\
\text { (i2. .9 }\end{array}$ & $\begin{array}{c}\text { Percent } \\
18.2\end{array}$ & $\begin{array}{l}\text { Meq. } \\
12.1\end{array}$ \\
\hline Cialitus & 3.2 & (i.9) & 28.5 & (iti.l 1 & 13.0 & 20.5 \\
\hline
\end{tabular}

in the nonheated sample. A sample of the fraction with equivalent spherical radius of less than $2 \mu$ was sealed in a fine thin-walled Pyrex glass capillary. The loaded capillary was then rotated for 6 hours at one revolution per minute in a Debye-Scherrer powder camera which had a radius of $57.3 \mathrm{~mm}$., using CuK $\alpha$ radiation $(\lambda=1.54)$, nickel filter, $35 \mathrm{kv}$. and $16 \mathrm{ma}$.

For the differential thermal analysis $100 \mathrm{mg}$. of $2 \mu$, organic matter-free clay were accommodated in a nickel holder. Chromel and alumel thermocouples were used. The initial voltage wats 86 and the initial temperature was $20^{\circ} \mathrm{C}$. The temperature was elevated to $1025^{\circ} \mathrm{C}$. Two Brown recording potentiometers were used, one for the furnace and the other for the thermocouples.

In all the above-mentioned analyses duplicates were run.

\section{RESLLTS ANI) IISCUSSION}

As shown in table 1 the two soils appear to have similar eontents of claty and organic matter. However, the cation-exchange capacity in (ralites clay was found to be higher than in (atalina clay by about 9 med. per $100 \mathrm{~g}$. 
Such a difference could be caused by a difference in the nature of the clay minerals. To investigate the existence of such possible differences, X-ray and differential thermal analyses were conducted.

Measurements of the position of the lines showed that, excluding traces

A

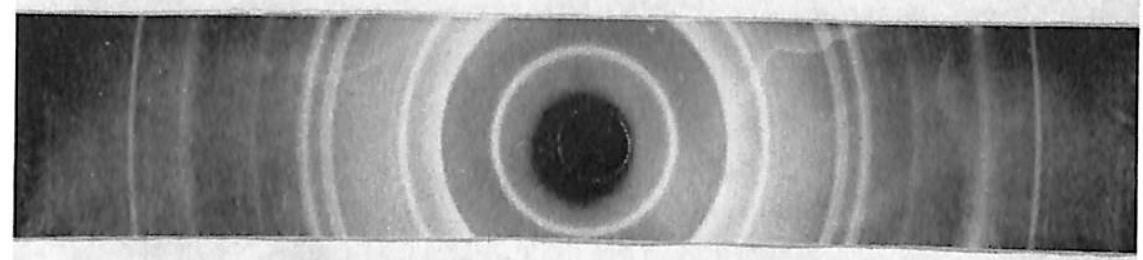

B

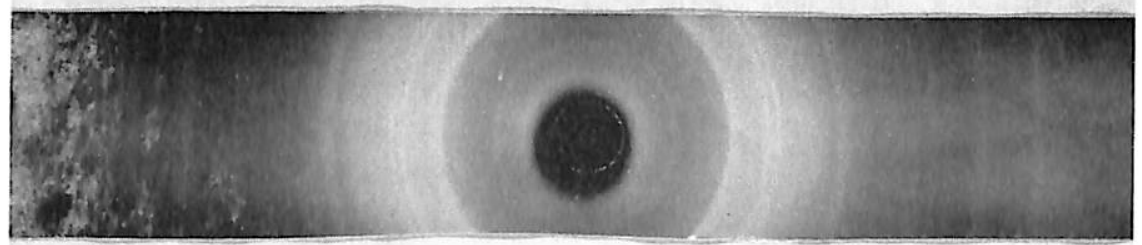

C.

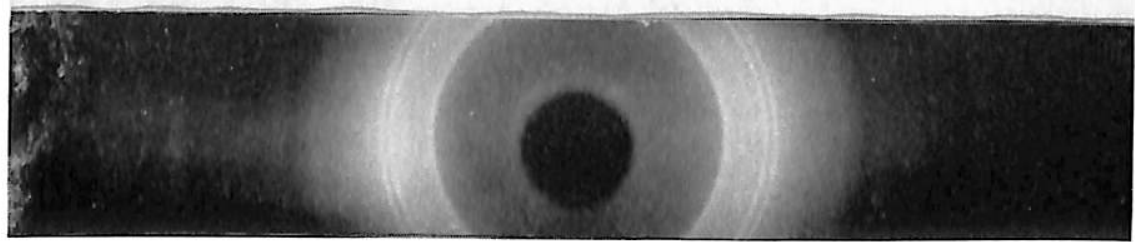

Fig. 1-X-ray films of Catalina clay: A, Unheated sample; B, heated to $500^{\circ} \mathrm{C}$; C, heated to $770^{\circ} \mathrm{C}$. Camera $=57.3 \mathrm{~mm}$.; contact print.

of quartz, every reflection was contributed by kaolinite. The X-ray patterns of the Catalina clay (fig. 1) and Cialitos clay (fig. 2) were virtually identical, especially insofar as the major reflections were concerned.

However, in Catalina clay the kaolinite was well crystallized, whereas in the Cialitos clay the kaolinite lattice structure was not well defined. This may well account for the difference in cation exchange capacity of the two 
soils, since the less the degree of crystallinity the higher the exchange capacity.

In order to check the results obtained by the $\mathrm{X}$-ray analysis with the idea of determining the predominant mineral in these soils, a differential thermal

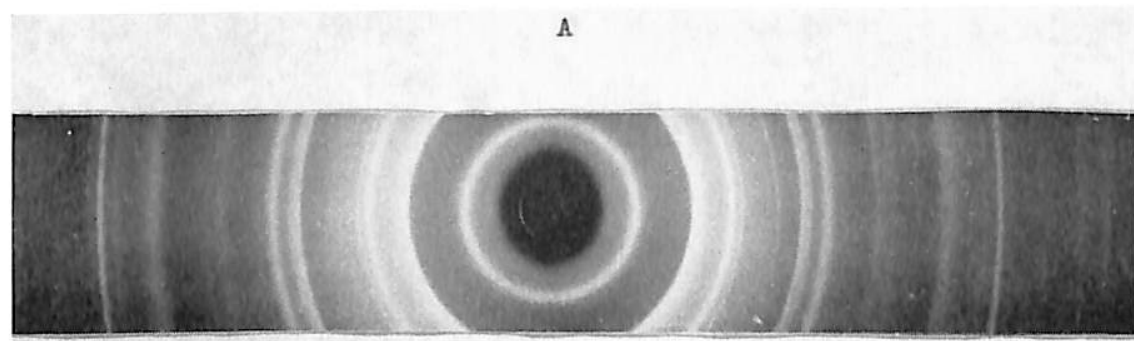

B

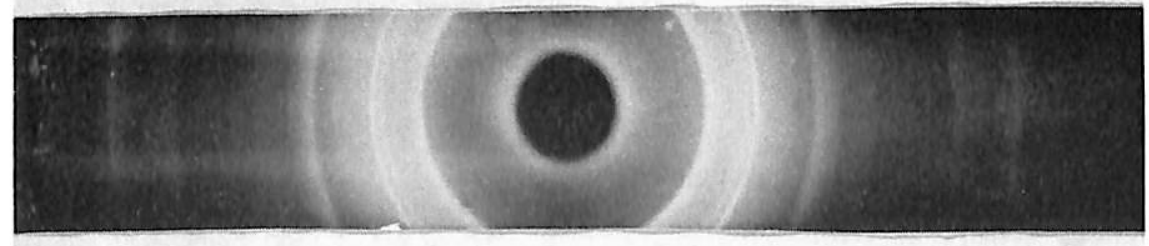

C

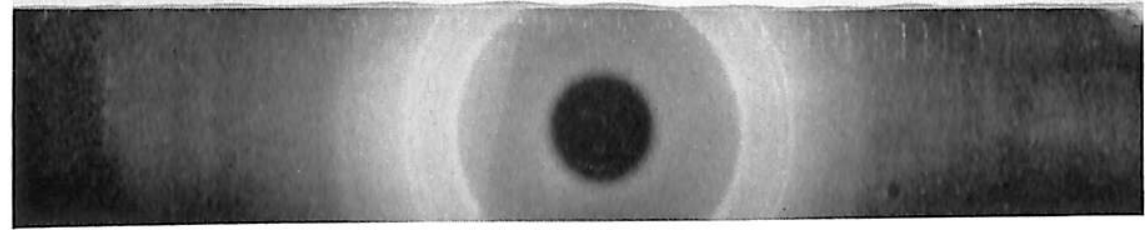

Fig. 2-X-ray films of Cialitos clay: A, unheated sample; B, heated to $500^{\circ} \mathrm{C}$; $\mathrm{C}$, heated to $700^{\circ} \mathrm{C}$. Camera $=57.3 \mathrm{~mm}$.; contact print.

analysis was made on samples of both soils. Two $\mu$ clay, free of organic matter, was separated for this determination.

The differential thermal curves (fig. 3) confirmed that there was a predominance of kaolinite in the clay of both soils. Gibbsite and goethite were also present, but in small quantities. When the areas under the exothermic and endothermic peaks were determined and plotted against the area from a kaolinite standard curve, it was found that Catalina clay contained only 40 percent of kaolinite while Cialitos clay had 35 percent. 
Cialitos clay showed a small initial endothermic reaction at $125^{\circ} \mathrm{C}$., indicating rather poor crystallinity of kaolinite. When there is irregularity in the arrangement of kaolinite units, a little water may be present between the layers. This is in accord with the slightly greater c-axis spacing of poorly crystallized kaolinites.
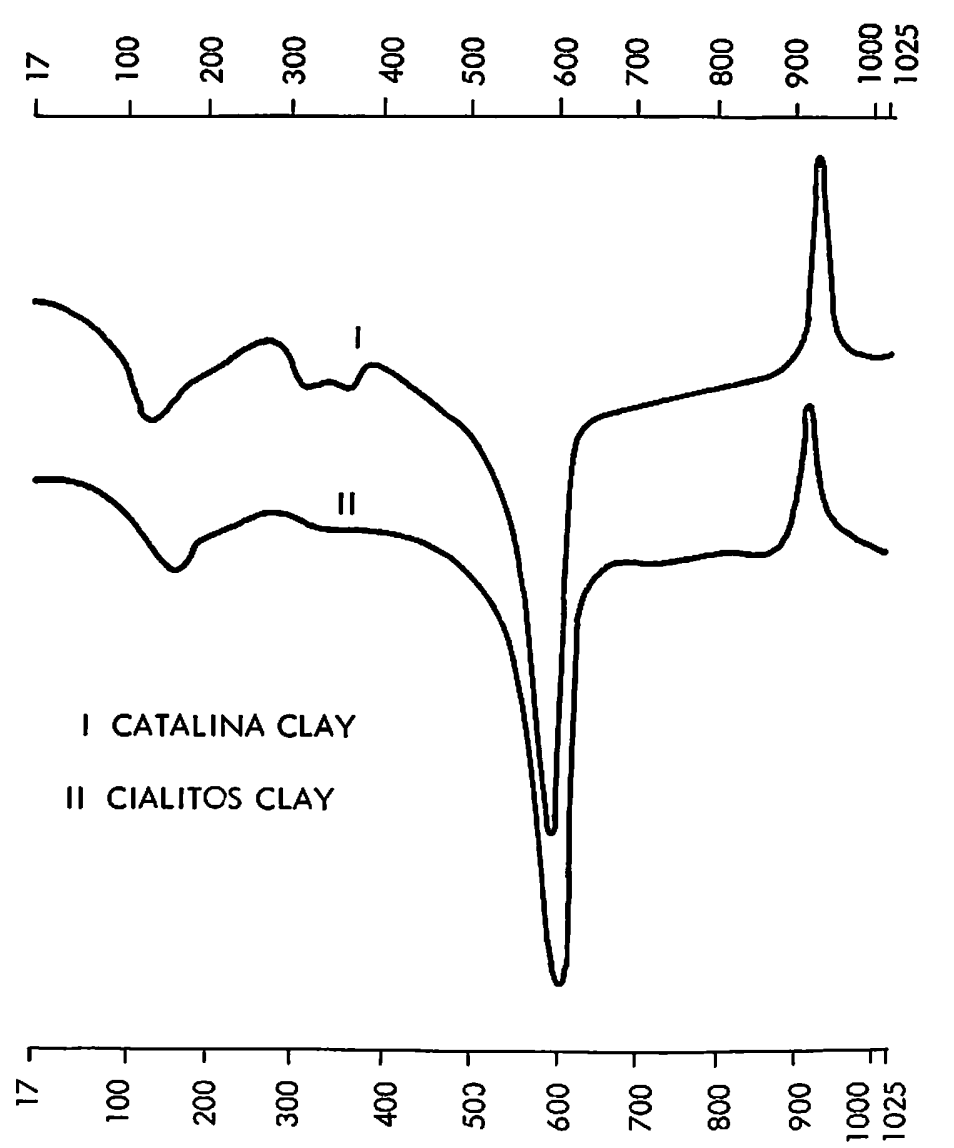

FIG. 3.-Differential thermal curves for Catalina clay and Cialitos clay.

The small peak shown at $320^{\circ} \mathrm{C}$. for Cialitos clay might represent $\mathrm{Fe}_{2} \mathrm{O}_{3} \cdot \mathrm{H}_{2} \mathrm{O}$. There was no indication of gibbsite.

The curve for Catalina clay at $370^{\circ} \mathrm{C}$. showed that gibbsite comprised about 0.5 percent of the clay fractions. $A$ portion of this peak was obscured by the $300^{\circ} \mathrm{C}$. peak, and was therefore interpolated. The peak at $300^{\circ} \mathrm{C}$. probably represents $\mathrm{le}_{2} \mathrm{O}_{3} \cdot \mathrm{H}_{2} \mathrm{O}$. It is too low for goethite, but may be lepidocrosite. 
Quantitatively, the X-ray analyses and differential thermal analyses did not fully agree, but the differences were ascribed to techniques in sample preparation and fundamental differences in the principles of the two methods. As was the case with X-ray analysis, after the coatings were removed, both clay samples appeared to consist of over 90 -percent kaolinite. With differential thermal methods keeping the clay coatings intact, the major exothermic and endothermic reactions were also contributed by kaolinite. Small quantities, less than 5 percent, of goethite, gibbsite, etc. were also indicated. Quantitative analysis based on area peaks of the $580^{\circ}-$ $600^{\circ} \mathrm{C}$. endothermic reaction indicated, however, that only 35 to 40 percent of kaolinite was present in the samples. There were no other major exothermic and endothermic reactions evident except those contributed by kaolinite. The portion of the sample unidentified by differential thermal analysis can be possibly attributed to amorphous or poorly crystallized material present in the clay. Some of this amorphous material probably existed as coatings, while other parts of it may have existed as amorphous particles mixed with kaolinite itself.

Alexander, Hendricks, and Nelson (2) stated that differential thermal methods do not appear trustworthy in estimating amounts of hydrous oxides of iron and aluminum. The endothermic peak, they maintain, is not so great, even though appreciable quantities may be present. As soon as they lose their water of hydration they merely behave like the reference material used, which is aluminum oxide.

Another possible reason for the difference in exchange capacity is the difference in free oxide content of the two soils. The Catalina soil has about 40 percent more $\mathrm{Fe}_{2} \mathrm{O}_{3}$ than the Cialitos soil. The development of $\mathrm{Fe}_{2} \mathrm{O}_{3}$ and $\mathrm{Al}_{2} \mathrm{O}_{3}$ alone or in the hydrated form has been considered and proven experimentally by Dion (3), as a cause in clogging exchange sites in kaolinitic clay minerals. Abruña and Smith (1) reported an increase in exchange capacity in several reddish tropical soils after removing the free oxides.

\section{SUMMARY}

Catalina and Cialitos soils have different cation exchange capacities, even though their organic-matter and clay contents are similar. X-r and $\Lambda \mathrm{v}$ differential thermal analyses were made on the clay fraction to determine whether this variation in exchange capacity could be attributed to differences in clay mineral composition. The analyses revealed that, in both cases, kaolinite is the predominant clay mineral. However, it was found that, in Cialitos clay, the kaolinite is poorly crystallized, whereas crystals are well defined in Catalina clay. Since the poorer the crystallinity, the higher the exchange capacity, this could account for the higher cation exchange capacity of Cialitos clay. Another factor that may also partly account for 
the difference in cation exchange capacity is the higher content of free iron oxides in Catalina clay. It is well known that free iron oxides block exchange positions in kaolinite clay minerals.

\section{RESUMEN}

Los suelos Catalina y Cialitos difieren en su capacidad para el intercambio de cationes a pesar de que contienen cantidades similares de materia orgánica y arcilla. Las fracciones arcillosas de estos suelos se sometieron a exámenes con rayos $\mathrm{X}$ y a análisis térmicos diferenciales (DTA) para determinar si las diferencias en la capacidad de intercambio de cationes podían atribuirse a diferencias en la composición mineralógica de la fracción arcillosa.

Los análisis revelaron que la caolinita predomina en dicha fracción en ambos casos. Sin embargo, se encontró que en la arcilla Cialitos la caolinita cristaliza pobremente, mientras que en la arcilla Catalina los cristales son bien definidos. Como se ha comprobado que mientras menos definida es la cristalización más alta es la capacidad de intercambio, se considera que esto podría explicar la razón por la cual la arcilla Cialitos posee una capacidad mayor de intercambio. Otro factor que puede explicar en parte la diferencia en capacidad de intercambio es el contenido de óxidos de hierro libres del suelo, que es mayor en el suelo Catalina arcilloso. Está comprobado que los óxidos de hierro libres bloquean las posiciones que normalmente ocuparían los cationes reemplazables en las arcilla caoliníticas.

\section{LITERATURE CITED}

1. Abruña, F., and Smith, R. M., Clay mineral types and related soil properties in Puerto Rico, Soil Soc. 75: 411-20, 1953.

2. Alexander, L. T., Hendricks, S. B., and Nelson, R. A., Minerals present in soil colloids: II. Estimation in some representative soils, Soil Sci. 48: 273-80, 1939.

3. Dion, H. G., Iron oxide removal from clays and its influence on base exchange properties and X-ray diffraction patterns of the clays, Soil Sci. 58: 411-24, 1944.

4. Jeffries, C. D., A rapid method for the removal of free iron oxides prior to petrographic analysis, Soil Sci. Soc. Amer. Proc. 11: 211-2, 1946.

5. Kilmer, V. J., and Alexander, J. T., Methods of making mechanical analyses of soils, Soil Sci. 68: 15-24, 1949.

6. Schollenberger, C. J., and Simon, R. H., Determination of exchange capacity and exchangeable bases in soil, ammonium acetate method, Soil Sci. 59: 13-23, 1945.

7. Walkley, A. and Black, T. A., An examination of the Degtjareff method for determining soil organic matter and a proposed modification of the chromic acid titration method, Soil Sci. 37: 29-38, 1934. 